\title{
The Impact of the Utilization of Riparian Area for Settlements (Case Study of North Jayapura District, Jayapura City)
}

\author{
Suwandi, Rahmat Daun \\ University of Cenderawasih Jayapura Papua, Indonesia \\ wandi1212@gmail.com
}

\begin{abstract}
The limitedness of area and plot of land in Jayapura City which are allocated for settlements has become a problem in Jayapura city. Population growth and high-rate of urbanization are impacted on the utilization of land which is not in accordance with its allocation. The modification of riparian area on the right and left sides of the river for settlements has reduced the function of the river, because in addition to river conservation, river has a double role as the securer of water source and as the protector of its surrounding area. Therefore, riparian area becomes more important to be considered. The riparian area in settlement area is assumed to be adequate for a 10-15 meters inspection road to be built on. The real condition of the rivers in North Jayapura District of Jayapura City, compared to the criteria of riparian area for settlement area, has not been inappropriate. The river's function as the protector of its surrounding area has gone astray. If there is someday a flood, the impact may cause material damage or even life victims.
\end{abstract}

\section{Keywords: Riparian Area, Settlement, North Jayapura}

\section{Introduction}

A city which is a life network marked by high population density and colored by heterogeneous social economic strata (Anthony, 1992), in the end may bring influence to the process of physical growth and development of the city itself. The city's physical growth and development are also influenced by the basic physical condition of a region or area such as topography and earth's relief of a region or area (Barnett, 1982). In addition to an aspect of requirement of the people of a certain activity which later will cause various phenomena imply on the utilization of city space and in general to the formation of the city's face. As one of the fundamental physical conditions in a region, river is an inseparable part to the growth and development of a city (Anthony, 1992). The utilization of river as transportation line will imply on various land utilization on its banks, where the utilization of these banks, in addition to bringing positive influence to the city's growth and development, it will also give a number of impacts to the growth of the city's problems (Djemabut, 1986). The condition developing in the area along the river banks has generally violated the Decree of the President of the Republic of Indonesia Number 32 of 1990 on the Management of Protected Area and the Regulation of the Government of the Republic of Indonesia Number 47 of 1997 on the National Spatial Plan which regulate the determination of riparian area lines and the application of riverside area as the local protected area (Kivel, 1993).

\section{Literature Review}

Riparian Area: Riparian area or floodplain is located between the river ecosystem and land ecosystem. Based on the Decree of the President of the Republic of Indonesia No. 32 of 1990 on the Management of Protected Area, riparian area is defined as the areas alongside the left and right of the river, including manmade river/canal/primary irrigation channel, which has vital role to maintain the function of the river. Riparian area includes river banks, namely part of the river body which is only covered by water in the rainy season and the riparian area on the outer part of the banks, namely the area receiving the water flooding in the rainy season and which has higher soil humidity compared to that in the land ecosystem (Merriam, 2005). Flood in the riparian area in the rainy season is a natural phenomenon having vital ecological function in maintaining the balance of environment and soil fertility. The banks are determined based on the relation between flood flow and the area of lower flow profile, usually above $1.0 \mathrm{~m}-1.5 \mathrm{~m}$ above the average low water face elevation (Sjarief, 1997). 
Riverbank Settlement: Riverbank settlement is generally a marginal settlement, because it sits on a land which is not allocated for buildings (Djemabut, 1986). The solution concerning wild settlement in the riverbank is by eviction or relocation of residents to a new place. The controlling of spatial utilization based on Act of the Republic of Indonesia No. 26 of 2007 on Spatial Planning is an activity related with supervision and policing towards the planning implementation, in order for the spatial utilization to be in accordance with the Spatial Planning (Department of Public Works, 1986). In Act of the Republic of Indonesia No. 26 of 2007 Article 35 it is explained that the spatial utilization control is performed through the stipulation of zoning, permit, incentives and disincentives, and sanctioning. The regulation is compiled based on the detailed spatial plan for each spatial utilization zone (Hasni, 2010). As an effort to restore the function of riverbank area as protected area but which is still can be utilized by the city people as a socially functioned area, the concept of riverbank area planning is created (Chay, 2004). The high requirement of activity space and the competence in urban land utilization causes the increase of land economic value, especially on the areas having commercial and strategic values, which in the end causes pressure and destruction towards areas related with the existence of public open spaces in the city (Jayadinta, 1999). Public open spaces such as city squares, parks, playgrounds, sport fields, are gradually disappearing, being replaced by buildings and inhuman pavements. The rarer open space in the cities will mean the lesser public spaces which are extremely required by the urban people on social and psychological needs (Kivell, 1993).

Spatial utilization along the riverbanks are extremely alarming: dense settlements grow projecting onto the river body, denudation of riverbank protecting plants, sand mining, to waste disposal, whether solid or liquid and industrial or household waste (Sjarief, 1997). Those matters will overall bring terrible impact to the riverbank area and will specifically impact to the water quality which will then be utilized by the city people for their own needs (Maryono, 2005). Such condition, and the rapid growth of urban population, will cause various urban problems, such as the requirements of space, degradation in the environment quality, housing and the consequence on the increase in the urban facility-infrastructure requirements (Kivell, 1993) will cause the physical condition of the riverbank area to be worsened if it is not quickly being anticipated by the city's policy makers.

\section{Methodology}

This research is quantitative which objective is to acknowledge the impact in the utilization of riparian area, which is divided by four factors, namely: the people's way of life, adaptation towards the river environment, physical factors and nonphysical factors. The people's way of life includes: the ways to make their living, sanitation and clean water, building orientation. Adaptation towards the river environment includes: building's structure and construction, building materials used and settlement patterns. The physical factors include: topography, river width, river's tidal cycle, flora and fauna. The nonphysical factors include: social interaction pattern and individual (social) needs. The total attributes of the five variables being analyzed are 12. There are 100 respondents being researched, who are spread in 5 villages located around the riparian area. The data analysis used is exploratory factor analysis (EFA) by SPSS software of version 20. The factor analysis can be used if the interdependence of the entire attributes are acceptable, namely the Kaiser-MyerOlkin (KMO) score is more than 0.50. EFA will result in a number of new factors consisting of several attributes to explain the total variety. Factor extraction will be optimized by choosing varimax rotation in order to give higher loading factor for each attribute.

\section{Results}

The factor analysis related with the impact of the utilization of riparian area is mostly described in the variety of materials and building patterns and the ways to make a living for the family. The factor extraction of the 12 indicators being analyzed is extracted to five components with cumulative contribution of $79.683 \%$. The first component with $30.261 \%$ contribution has high loading factor (more than 0.50 ) in building materials, building patterns and ways to make a living. The three attributes are in one factor because they have stronger correlation. The pattern of houses built on the riparian area will use different materials compared to those in the settlement area. The shape and materials of the houses will have relation of the residents of riverbank settlements and the river such as bathing, washing, toilet activities and waste, socio-cultural activities and the 
needs of clean water and drinking water. The second component with $16.377 \%$ contribution represents the indicators such as sanitation and clean water, building orientation and house structure. Living in the riparian area will face numerous risks such as flood and low quality sanitation.

Table 1: Summary of Exploratory Factor Analysis

\begin{tabular}{lllllll}
\hline Description & Label & \multicolumn{7}{l}{ Component } & \multicolumn{3}{l}{} & \\
& & $\mathbf{1}$ & $\mathbf{2}$ & $\mathbf{3}$ & $\mathbf{4}$ & $\mathbf{5}$ \\
\hline Building material & MATERIAL & $\mathbf{0 . 9 1 7}$ & 0.098 & 0.183 & 0.074 & 0.069 \\
Building pattern & PATTERN & $\mathbf{0 . 9 0 5}$ & 0.018 & 0.216 & 0.021 & 0.014 \\
Way of living & LIVELIHOOD & $\mathbf{0 . 8 2 5}$ & 0.130 & -0.197 & 0.046 & 0.184 \\
Sanitation and clean water & SANITATION & -0.037 & $\mathbf{0 . 8 3 2}$ & 0.041 & 0.057 & 0.291 \\
Building orientation & BUILDING & -0.015 & $\mathbf{0 . 7 8 0}$ & 0.462 & -0.094 & 0.019 \\
House structure & STRUCTURE & 0.360 & $\mathbf{0 . 7 5 9}$ & -0.008 & 0.064 & 0.056 \\
Tidal cycle & CYCLE & -0.003 & -0.002 & $\mathbf{0 . 8 6 6}$ & 0.135 & 0.126 \\
Topography & TOPOGRAPHY & 0.236 & 0.343 & $\mathbf{0 . 7 5 4}$ & -0.036 & 0.103 \\
Individual needs & NEED & -0.039 & -0.021 & -0.037 & $\mathbf{0 . 9 1 7}$ & 0.064 \\
Social interaction & INTERACTION & 0.164 & 0.063 & 0.145 & $\mathbf{0 . 8 8 5}$ & -0.094 \\
River width & WIDTH & 0.031 & 0.173 & 0.011 & -0.120 & $\mathbf{0 . 8 4 2}$ \\
Flora and fauna & FLORAFA & 0.196 & 0.100 & 0.223 & 0.110 & $\mathbf{0 . 7 8 0}$ \\
Eigen Score & & 3.631 & 1.965 & 1.649 & 1.213 & 1.103 \\
\% Total Variant & & 30.261 & 16.377 & 13.745 & 10.109 & 9.192 \\
\% Cumulative Variant & & 30.261 & 46.637 & 60.382 & 70.491 & 79.683 \\
\hline
\end{tabular}

$\mathrm{KMO}=0.657$; Non-redundant residual is more than $0.05=33 \%$

The next three components are cycle and topography (13.745\%), social (10.109\%) and environment (9.192\%). The topography condition as the place where people live will have strong correlation with the impact to be caused of the river's tidal cycle. In the rainy season, the river surface height will increase and in certain topography will give serious impact to the residents. However, this component is on the third factor that the variety of problems in this factor has decreased. Control of riparian area and flood plain in the built up area will be performed in order to restore the area's functions (Wang \& Pei, 2012). The built up area in the riparian area will gradually be restored to its initial function, namely to maintain the conservation of river function, in accordance with its criteria and technical standard. This function is restored by increasing the hydrologic function of riparian area and by not allowing construction of new buildings in the area, in order to not develop further unless old buildings which are developed vertically and buildings which support the area's function and is a building constructed for public interest and tourism. The fourth factor is the social factor which includes individual requirements in fulfilling the social interaction requirements. Living in the riparian area will be different because of a number of factors and patterns of the changes of lives in the riverbank which may be influential. Several influences are the increase of houses in number due to population growth and urbanization, the increase of circular lines, the desire to have a decent house and easiness, to obtain daily needs without spending money due to the resident's financial limitedness. The fifth factor is environment, which includes river width and the changes of flora and fauna (Gyawali et al., 2013). The riparian area will experience the dynamics which require supervision to avoid disaster. The people living in the riparian area must be able to utilize the existing land to increase their role in managing the flood plain (Yang et al., 2010). Utilizing the organizational role to implement policies related with riparian area and flood plain area. Creating the opportunity for the people's organization/NGOs and the people in the riparian area settlement and flood plain area.

\section{Conclusion}

Riverbank settlement should be controlled because it has peculiarity in terms of its people's interaction with the river. The formulized concept, in addition to its settlement arrangement and the networking of the settlement itself, is the economic system and environmental conservation concept. The overall concept is the revamping of economic activity development in the river, settlement arrangement which includes mass arrangement and building display, green open space, environmental sanitation and ecosystem conservation which supports the river. The conclusion for settlement on the riverbank is by inviting centers of economic 
activities and urban recreation as the efforts to improve the economic condition or standard of living of its people. The improvement of the standard of living is reached by the improvement of knowledge and skills through workshops and provisioning of jobs.

\section{Reference}

Anthony, J. C. (1992). Perencanaan Kota. Jakarta: Erlangga.

Barnett, J. (1982). An Introduction to Urban Design. New York: Harper \& Row

Chay, A. (2004). Hidrologi dan Pengelolaan Daerah Aliran Sungai. Yogyakarta: Gajah Mada University Press.

Departemen Pekerjaan Umum. (2006). Konsep Dasar Panduan Penyusunan Peraturan Zonasi Kawasan Perkotaan

Djemabut, B. (1986). Perumahan dan Permukiman, Yayasan Obor Indonesia.

Gyawali, S., Techato, K., Yuangyai, C. \& Musikavong, C. (2013). Assessment of relationship between land uses of riparian zone and water quality of river for sustainable development of river basin, A case study of U-Tapao river basin, Thailand. The $3^{\text {rd }}$ International Conference on Sustainable Future for Human Security SUSTAIN 2012 Procedia Environmental Sciences, 1 7, 291 - 297.

Hasni. (2010). Hukum Penataan Ruang dan Penatagunaan Tanah, cetakan kedua, Rajagrafindo Persada, Jakarta.

Jayadinta, T. J. (1999). Tata Guna Tanah Dalam Perencanaan Pedesaan, Perkotaan, dan Wilayah: Edisi Ketiga. Bandung: ITB

Kivell, P. (1993). Land and the City: Pattern and Process of Urban Change. London: Routledge

Maryono, A. (2005). Menangani Banjir, Kekeringan dan Lingkungan. Gama Press.

Yang, M., Qia, X., Zhang, Y., Sheng, J. \& Shen, D. (2010). Assessing Alternatives for Sustainable Management of a Flood Control Dam. International Society for Environmental Information Sciences 2010 Annual Conference (ISEIS). Procedia Environmental Sciences, 2, 98-110

Merriam, D. H. (2005). The Complete Guide to Zoning. New York: McGraw-Hill.

Sjarief, R. (1997). Kawasan Pedesaan Ditinjau Dari Sistem Tata Air Daerah Aliran Sungai (DAS). Jurnal Perencanaan Wilayah dan Kota, 8(1).

Undang-undang No 26 Tahun 2007 tentang Penataan Ruang

Undang-Undang Nomor 7 tahun 2004 tentang Sumberdaya Air.

Undang-Undang Republic Indonesia Nomor 1 Tahun 2011 tentang Perumahan dan Kawasan Permukiman.

Wang, Z. \& Pei, Y. (2012). Ecological risk resulting from invasive species: a lesson from riparian wetland rehabilitation. The 18th Biennial Conference of International Society for Ecological Modeling. Procedia Environmental Sciences, 13, 1798-1808. 